\title{
The Effect of the Board Composition on Dividends: The Case of Brazilian and Chilean Family Firms
}

\author{
Guadalupe del Carmen Briano-Turrent ${ }^{\mathrm{a}^{*}}$, Karen Watkins-Fassler ${ }^{\mathrm{b}}$, Martha Luisa Puente-Esparza ${ }^{\mathrm{a}}$ \\ aFacultad de Contaduría y Administración, Universidad Autónoma de San Luis Potosí, Mexico \\ bFacultad de Empresa y Comunicación, Universidad Internacional de La Rioja (UNIR), Facultad de Empresa y Comunicación, Spain
}

Received 2020-09-14; accepted 2020-10-20

\section{JEL CLASSIFICATION L20, 031 \\ KEYWORDS \\ Dividend policy, Family firms, Board composition, Latin America, Agency theory}

\begin{abstract}
Based on the agency theory, this paper analyzes whether family firms pay more dividends compared to no-family firms and identifies whether the board composition affects the dividend policy. Brazil and Chile have established mandatory dividends, retain lower cash holdings, pay higher dividends compared with other markets in the region. The sample of study is composed by 853 observations from 49 Brazilian and 32 Chilean top publicly listed firms in terms of market capitalization over the 11-year period from 2004 to 2014. Using an unbalanced panel data, results indicate that family controlled firms distribute more dividends and board composition namely; board size and the proportion of women on the board have a significant and positive impact on the dividend policy of the firm. By contrast, Chairman of Board - Chief Executive Office (COB-CEO) duality signficantly. Thus, dividend policy constitutes an effective corporate governance mechanism in mitigating the family' expropriation of minority shareholders' wealth.
\end{abstract}

El efecto de la Junta Directiva y la propiedad y el control familiar sobre los dividendos: El caso de las empresas brasileñas y chilenas

Resumen Basado en la teoría de la agencia, este documento analiza si las empresas familiares pagan más dividendos en comparación con las empresas no familiares e identifica si la composición de la junta directiva afecta la política de dividendos. Brasil y Chile han establecido dividendos obligatorios, mantienen menores tenencias de efectivo y pagan dividendos más altos en comparación con otros mercados de la región. La muestra del estudio está compuesta por 853 observaciones de 49 empresas brasileñas y 32 chilenas principales que cotizan en bolsa en términos de capitalización de mercado durante el período de 11 años de 2004 a 2014. Utilizando datos de panel no balanceados, los resultados indican que las empresas controladas por la familia distribuyen más dividendos y composición de la junta, a saber, el tamaño del directorio y la proporción de mujeres en el directorio tienen un impacto significativo y positivo en la política de dividendos de la empresa. Por el contrario, la dualidad Chairman of Board - Chief Executive Office (COB-CEO) tiene un efecto negativo. Por lo tanto, la política de dividendos constituye un mecanismo de gobierno corporativo eficaz para mitigar la expropiación familiar de la riqueza de los accionistas minoritarios.

https://doi.org/10.24310/ejfbejfb.v10i2.10177

Copyright 2020: Guadalupe del Carmen Briano-Turrent, Karen Watkins-Fassler, Martha Luisa Puente-Esparza

European Journal of Family Business is an open access journal published in Malaga by UMA Editorial. ISSN 2444-8788 ISSN-e 2444-877X This work is licensed under a Creative Commons Atribution-NonCommercial-ShareAlike 4.0 International License (CC BY-NC-SA 4.0). 


\section{Introduction}

Dividends may be defined as the distribution of the firm earnings among the shareholders of the company in proportion of their ownership. Dividends constitute a signal mechanism to the stock market because they communicate information about the financial performance and therefore impact the share price (Roy, 2015). There are several factors that may influence on the dividend policy. As from the seminal work of Miller and Modigliani (1961), different studies have analyzed explanations for dividends behavior. In the context of family firms, the agency theory provides a mixed perspective on moral hazard problems in family firms. On the one hand, families are assumed to be better monitors of management than other types of large shareholders, suggesting that lack of alignment between principal (controlling shareholders) and the agent (managers) better known as Agency Problem I, might be less prevalent in family than in non-family firms (Anderson \& Reeb, 2003; Ben-Amar \& André, 2006). On the other hand, controlling families may have an incentive and the ability to extract private benefits at the expense of minority investors (referred to here as Agency Problem II) (Bozec \& Laurin, 2008; Fama \& Jensen, 1983; Shleifer \& Vishny, 1997).

Recently, family firms have attracted the attention of many researchers, not only for their unique characteristics but also because to their economic contribution to the economic development (e.g., Chen et al. 2005; Pindado et al. 2012; Setia-Atmaja et al., 2009; Yoshikawa \& Rasheed, 2010). Family firms account for two thirds of all businesses around the world, contribute with the 70\%-90\% of the Gross Domestic Product (GDP) annually, and create the $50 \%-80 \%$ of total employment (Family Firm Institute, 2016). Family businesses are currently recognized by corporate, academic and government entities, as the leading source of jobs and wealth creation, both in developed and emerging countries (Schio, 2017). Data from Latin America shows that family firms represent the $75 \%$ of firms (McKinsey \& Company, 2014), generate the $70 \%$ of job creation and contribute to about $60 \%$ of the GDP (EY, 2014). In Latin America, large domestic conglomerates dominate the business sector. Many of these type of groups started during the 1950s, period of import substitution in the region, while the privatizations reforms of the 1980s and 1990s gave rise to a second wave of large conglomerates. Essentially, the great majority of these conglomerates are family firms with several generations in the same company $(47 \%$ are managed by the first generation, $29 \%$ by the second generation and $10 \%$ by the third generation), and usually family members exercising the control through the own- ership concentration or holding leadership positions (Aguilera \& Crespi-Cladera, 2012; Parada et al., 2016).

In Brazil, the $70 \%$ of the largest public business are family-owned and the $90 \%$ of private companies are family, while these types of companies create the $75 \%$ of all new jobs (Cambieri, 2012). With respect to dividends, the corporate law in Brazil requires that listed firms specify the percentage of annual profits (normally 25\%) to be paid out as dividend in their bylaws, and dividends from Brazilian companies are not taxed (Martins \& Novaes, 2012). In the Chilean context, $44 \%$ of listed companies are family owned while the $49.6 \%$ of small and medium companies are family firms. These companies contribute with $70 \%$ of the GPD and generate the $60 \%$ of employment (Watkins-Fassler et al., 2016). Similarly to Brazil, the Chilean Corporation Act requires from open stock companies, to distribute at least 30\% of their net income each year as dividends, unless otherwise agreed by the unanimous consent of the shareholders (Gutiérrez et al., 2012). The Brazilian capital market is characterized by a higher ownership concentration, pyramidal management structures and the presence of institutional investors (pension funds), which have contributed to the efficiency and liquidity of the market (Lefort \& Walker, 2007).

The prevalence of family firms in Latin America and the family incentive to extract private benefits raises the question: how family firms adopt dividends to reduce free cash flow and restrict their opportunistic behavior? Family firms that operate within weak institutional environments may distribute higher dividends as a trust-generating mechanism towards minority investors (Gomez-Mejia et al., 2010; Miller et al., 2010). Furthermore, dividend policy is a more credible signal against the minority expropriation investors compared to other corporate governance mechanisms (Pindado et al., 2012). On the other hand, board of directors also plays an important role in mitigating agency problems between families and minority shareholders (Fama \& Jensen, 1983). The inclusion of independent or female members on the board generally increases the monitoring and restricts the opportunistic behavior of controlling shareholders (Gunasekarage \& Reed, 2008). Namely, the board composition may balance (mitigate) the family's power (agency problems) between family and outside investors (Setia-Atmaja, 2010).

From the agency theory perspective, this paper focuses on the Agency Problem II (principal-principal) that is interesting when studying dividends, namely the conflict between the controlling and minority shareholders, who may have diverging interests due to their different preferences 
to maintain the control or corporate resources (Faccio et al., 2001). Minority shareholders often prefer to receive dividends in order to reduce the free cash flow available for the controlling shareholders, whereas the controlling shareholders adopt a reinvestment preference (Gersick et al., 1997). These conflicts of interests motivate the expropriation of minority shareholders and, consequently increase the agency problems type II in family firms. In this context, dividends play a disciplining role by forcing controlling shareholders to abstain from expropriation behavior and to pay out (high) dividends (Michiels et al. 2015). This study aims to respond two main empirical questions related to family firms' dividend policy. First, do Brazilian and Chilean family publicly listed firms distribute more dividends to shareholders compared with non-family firms in order to inhibit agency problems between controlling and minority shareholders? Second, does the board composition affect dividend policy decisions in family firms in these countries? This study extends the international literature on two fields of increasing interest to practitioners and scholars: corporate governance and family firms. The sample of study is composed by 49 Brazilian (IBOVESPA) and 32 Chilean (IPSA) top publicly listed firms in terms of market capitalization (853 observations over the 11-year period from 2004 to 2014), excluding the banking sector companies. An unbalanced panel data is performed through different econometric analysis (panel data and Logit models) to demonstrate if family firms distribute more dividends, and how the board composition may affect this relationship. Empirical results demonstrate that family firms pay more dividends than non-family firms, while the board size and female representation on the board have a significant and positive impact on the dividend policy of the firm. In contrast, the COB-CEO duality inhibits dividends. These results support the "substitute" model proposed by La Porta et al. (2000), which affirms that firms with high levels of ownership concentration pay more dividends to alleviate the Agency Problem II and enhance reputation. Good governance practices, such as an adequate board structure, lead to a more efficient dividend policy (Michiels et al., 2015).

This paper makes several contributions. First, this study shows that policy dividend is a mechanism adopted by Brazilian and Chilean family listed companies to align the interests between the controlling and minority shareholders, since the region is characterized by a higher ownership concentration and a weak legal system. Corporations operating in such environments are more likely to increase dividends in order to reduce the opportunist behavior by controlling fami- lies. Thus, this research offers an opportunity to examine the key role that family firms play in determining the dividend policy, particularly in the presence of weakness in the institutional framework. Second, this study is pioneer analyzing the relationship between the family element, board composition and dividend policy, and contributes to the international literature analyzing Brazil and Chile, which represent two of the largest emerging economies in the world and whose institutional peculiarities and market culture differ from other contexts studied in the prior research (e.g., Anglo-Saxon and European countries). Large domestic conglomerates controlled by families dominate the business sector in Brazil and Chile. Furthermore, Brazil and Chile have established mandatory dividends in Latin America (Lozano \& Caltabiano, 2015). Therefore, results may vary compared with other contexts where dividends are voluntary and where the ownership pattern is dispersed.

Third, the study compares the behavior between family and non-family firms on dividend policy and emphasizes the relevance of the board structure on strategic financial decisions. While the interacting roles of some corporate governance mechanisms have been documented in prior research, little is known about the role of dividends and board structure on Latin American family controlled firms. If family firms distribute more dividends and nominate more independent and female members on their boards, this should signal that controlling families are not deviating resources from minority investors and therefore the Agency Problem II may be alleviated. Finally, this research has important social and practical implications for policy makers and family founders to make knowledgeable decisions and thus increase the competitiveness and economic growth. For instance, most of family firms still use conservative sources of capital (EY, 2014), thus, policy makers need to promote policies that inhibit family opportunistic behavior in detriment of minority shareholders and increase the participation of institutional investors in providing capital in Latin America.

The remainder of the paper is organized as follows. Section 2 provides the theoretical framework and hypothesis development. Section 3 describes the sample and methodology of study. Section 4 discusses the empirical results. Section 5 concludes the research.

\section{Literature Review and Hypothesis Development}

2.1. Institutional framework in Brazil and Chile According to Martins and Novaes (2012), only five countries with civil law adopt mandatory 
dividends, which are Brazil, Chile, Colombia, Greece, and Venezuela. Among these five countries, two of them (Brazil and Chile) are analyzed in this study. Brazil and Chile have common market characteristics and corporate governance approaches (Cueto \& Switzer, 2015). Brazil represents a large Latin American economy, while Chile, though smaller, has had a more stable economy over the last 20 years (Chong \& Lopezde-Silanes, 2007).

The legal systems in the two countries have the same origin (civil law country), but they differ greatly in investor protection. La Porta et al. (1998) have created an anti-director rights index to measure the degree of shareholder protection in 49 countries. Brazil and Chile obtain different levels of anti-director rights within the region. The value of the index is 2 for Brazil and 5 for Chile. High concentration levels in voting rights are found in Brazil, and these are leveraged by the widespread use of indirect control structures and nonvoting shares. In Chile cross holdings are not allowed, and indirect control structures are very common; however nonvoting shares are unusual (Leal \& Carvalhal-da-Silva, 2007).

Capital markets in Brazil are undeveloped compared to other developed economies and high interest rates limit the companies' access to external capital (Crisóstomo et al., 2013). The Brazilian financial system relies heavily on banks, as is usual in developing civil law economics, and in the last few years have reached the highest real interests in the world, which in turn leads to a rationing of credit in the country (Laux, 2006). According to Al-Najjar (2013), companies from Brazil had the lowest cash holding levels as a result of excessive spending (agency problems). In this context, companies depend on liquidity and of those stricter conditions for accessing to external capital. Because Brazilian firms tend to inhibit amounts of cash, it is reasonable to affirm that the cash flow generated is exercised through dividends.

With respect to the regulatory framework, Brazil has gone through several changes in its tax legislation on dividends in the last two decades. There were four major changes in the Brazilian legislation between 1986 and 2004 (Zagonel et al., 2018). In the period January 1980 - December 1988, dividends were taxed with three different rates: $23 \%$ if the company was publicly listed (except for agriculture industry), $15 \%$ if the distributing company was from the agriculture sector, and $25 \%$ for all remaining cases. From February 1989 to January 1996, several changes were introduced in the tax legislation. For instance, the tax imposed for distribution as of $15 \%$ flat rate, while in 1996, the concept of "interest on equity capital" was adopted. This addition allows firms to partially deduct payments of dividends as operating expenses. In 2001, 10303/2001 Act reduced the maximum proportion of nonvoting shares to $50 \%$, applied only to Initial Public Offering. Also in 2001, Bovespa launched its "Novo Mercado" (New Market), a special listing segment for companies that voluntarily adopt additional corporate governance practices and transparency requirements compared to those already requested by the Brazilian Law and the Brazilian Securities and Exchange Commission. Such especial segment requires complying the principle "the one vote-one share". Currently, the Brazilian Corporations Law requires all publicly firms to include in their Bylaws a percentage of the annual profits, typically $25 \%$ to be paid out as dividends, although a significant fraction of Brazilian firms use loopholes of the law to avoid paying dividends (Martins \& Novaes, 2012). Dividends are distributed from the net profits, after the payment of income tax and social contributions and fees. The Brazilian Securities and Exchange Commission play a strategic monitor role on the dividend policy, since may curb the undue retention of dividends and may result in penalties if the retention is not justified. Under this context, the effectiveness of the law explains why the average dividend yield in Brazil is higher than in the U.S. Therefore, the new legislation aims to reduce the discretion of majority (voting) shareholders in the expropriation of minority (nonvoting) shareholders through the dividend policy (Zagonel et al., 2018). BOVESPA is the unique stock-trading center in Brazil and accounts for about $70 \%$ of the trading volume in Latin America (Cueto \& Switzer, 2013).

The Chilean legal system is based on the French Civil Code and the most of corporate laws are imposed and monitored by the Government. Corporate Chilean laws were inspired from American laws. Chilean economic groups control $70 \%$ of listed companies and $90 \%$ of their assets. Control concentration is also high in Chile, but larger in Brazil. The five largest shareholders indirectly control $57 \%$ in Chile and $89 \%$ in Brazil. There are no codes of good governance or voluntary practices self-imposed by business sector (Gutiérrez et al., 2012). The Chilean capital market is characterized by high market capitalization and low turnover, with more that two decades of substantial participation by institutional investors (Lefort \& Walker, 2007). According to Lefort and Walker (2000), the Chilean market is characterized by a highly concentrated ownership, economic groups are the predominant form of corporate structure and that the most common way of separating control from cash flow rights is through pyramids schemes. For instance, $70 \%$ of listed nonfinancial companies in Chile belong to one of the approxi- 
mately 50 conglomerates controlling, which represent $91 \%$ of total assets of nonfinancial firms registered in the Chilean Stock Exchange. Furthermore, controllers of conglomerates participate serve as board members and hold more equity than strictly needed for control, suggesting that cash flow benefits associated to subsidiaries are relatively large. Finally, pension funds and ADRs constitute significant minority shareholders in Chilean groups.

The securities market law and the corporation's law comprise the legal framework governing capital markets and the actions of listed companies in Chile. These laws were written in 1981 and amended in 1989 and more deeply in 1994. Recently, both laws were amended by the corporate governance law of 2000 (Lefort \& Walker, 2007). With respect to the dividend policy in Chile, it is required to pay at least $30 \%$ of their earnings as mandatory dividends. Shareholders are entitled to receive dividends per share and the unanimous vote of all of the issued and outstanding share is required to distribute dividends. Dividends and other profit distributions derived by non-residents are subject to a final withholding tax (non-resident income tax) at the rate of $35 \%$ on the gross amount (IBFD, 2017).

\subsection{Hypothesis development}

\subsubsection{Family firms and dividends}

In the context of publicly listed firms, the agency theory suggests that dividend policy may serve to reduce agency problems between controlling and minority shareholders as it forces to controlling investors to raise funds from capital markets by reducing the firm's free cash flow (Easterbrook, 1984; Jensen, 1986). La Porta et al. (2000) affirm that dividends are an ideal device for limiting minority shareholders wealth expropriation and propose two models to explain the role of dividend policy as corporate governance mechanism. The "outcome model", predicts a positive relation between dividend policy and corporate governance because minority shareholders can force managers to disgorge cash under effective legal system and strong corporate governance. On the other hand, the "substitute model" affirms that paying dividends could be a substitute of the weak shareholder protection. Firms with a weak corporate governance or low investor protection environment need to pay more dividends to establish good reputation in order to increase funding from capital markets. This suggests family controlled firms use dividends as an effective governance mechanism in mitigating the families' expropriation of minority shareholders' wealth (Setia-Atmaja et al., 2009).

From the agency theory perspective, family firms reduce agency costs, since there is an alignment between owner-managements' interests (Fama \& Jensen, 1983; Jensen \& Meckling, 1976). This alignment reduces the opportunistic behavior, preventing the maintenance of agency costs for separating the management and control decisions (Setia-Atmaja, 2010). According to the traditional agency theory's premises, dividends are indeed assume to be irrelevant in these firms because of the absence of a principal-agent conflict of interest and a strong natural alignment of incentives between family shareholders (Michaely \& Roberts, 2012). Therefore, families have greater incentives to monitor managers than other type of shareholders such as institutional investors (Anderson \& Reeb, 2003). In the context of emerging countries with higher levels of ownership concentration, Aivazian et al. (2003) found that companies pay out higher dividends and conclude that the institutional framework has a significant influence on the dividend policy. Fatemi and Bildik (2012) found that civil law countries distribute more dividends than countries with high shareholder protection.

However, in reality, family firms may incur in other type of agency costs. For instance, the reluctance of families to fire incompetent family members on top positions may increase agency costs and nepotism practices. Additionally, family firms have powerful incentives to expropriate wealth from minority investors and those incentives are strongest when family control is greater than its cash flow rights (Faccio et al., 2001). The intrafamilial principal-principal conflict is particularly interesting when studying dividends, namely the one between active shareholders (who participate in the firm's taking decisions) and passive family shareholders (minority shareholders who often prefer receive dividends, in order to reduce the free cash flow available for the controlling shareholders) (Gersick et al., 1997; Maug, 2002). This divergence of interests between active and passive shareholders may have detrimental effects for family firms, and consequently to increase agency conflicts. In this context, corporate governance mechanisms such as dividends could be a potential solution for the potential principal-principal conflict. For instance, the stock market will play a disciplining role by forcing controlling shareholders to abstain from expropriation behaviour and to pay out high dividends (Michiels et al., 2015).

Empirical evidence on the relationship between family firms and dividend policy is inconclusive. For instance, González et al. (2014) support that family participation on the ownership negatively affects dividends, while family members on the board have a positive influence on dividend policy. Michiels et al. (2015) show that the existence of an intra-familial conflict of interest results in a higher propensity to pay dividends. They sug- 
gest that using family governance practices leads to a more efficient dividend policy. In the same line, Setia-Atmaja et al. (2009), Yoshikawa and Rasheed (2010) and Pindado et al. (2012) evidence those family firms pay out more dividends than non-family firms in Australia, Japan, and nine European countries, respectively. By contrast, Villalonga and Amit (2006), Khan (2006), and Gonzalez et al. (2017) show a negative relationship between family ownership and dividends in the U.S., U.K., and six Latin American countries, respectively. Chen et al. (2005) do not find any significant relationship between dividend and family ownership in Hong Kong.

Thus, how family ownership affects dividend policy depends not only on potential agency issues but also on legal environment related to shareholder protection. Particularly, Brazil and Chile are characterized by high ownership concentration and mandatory dividends, which suggest that family firms may distribute higher dividends to alleviate the expropriation towards minority investors (although the weakness on the investor protection is higher for Brazil, the Latin American is characterized by a poor investor protection compared with other developed regions). Thus, the first hypothesis is formulated as follow:

H1. Family listed firms distribute a higher proportion of dividends than non-family firms in Brazil and Chile.

\subsubsection{Board of directors and dividends}

Corporate boards play an important role in monitoring and disciplinary functions. One of firm's major financial decisions that lie in the hands of the board is dividend policy (Alias et al., 2014). In the presence of high agency costs of free cash flow, the board of directors may influence the corporate performance through dividends. For instance, if family firms distribute less dividends, they could nominate independent or women on the board, which constitutes a positive signal to the capital markets, and therefore, Agency Problem II is reduced (Setia-Atmaja et al., 2009).

The composition of the board (independence, size, duality, and diversity) may favor its effective supervisory role. For instance Hossain et al. (2001) found a direct effect of board composition and firm performance. Adjaoud and Ben-Amar (2010) supported that the board composition is positively related to payout ratio, concluding that firms with stronger corporate governance distribute more dividends. For instance, independent directors are an effective monitoring device in the agency conflicts and balance the family's power (Anderson \& Reeb, 2004).

Independent directors are generally more prepared, have more experience and act effi- ciently in their supervisory role. In this sense, independence of the board may reduce agency problems and increase the distribution of dividends (Farinha, 2003). Prior studies have found that independent directors are likely to promote decisions that are in the interests of minority shareholders, and consequently, stock markets react favorably to the appointment of outside directors (Brickley et al., 1997). Specifically, independent directors increase the effectiveness of monitoring function over the management and family members' decisions on the board. Under the above discussion the following hypothesis is established:

H2. Dividends are positively affected by independent members on the board in listed firms from Brazil and Chile.

Board size is referred to the number of directors serving in the board. According to Klein (2002), larger boards promote a higher specialization of their members, which leads to a more effective monitoring role and, therefore, the distribution of dividends could be increased. However, larger boards may be less effective than the small ones and make the decision making process more difficult (Jensen, 1993). Family firms have a preference for large boards and the inclusion of family members is a common practice. However, if family firms pursue to increase trust in the markets, they may opt for larger and more independent boards that comply more effectively their monitoring function and reduce the potential principal-principal agency conflict in family controlled firms (Bartholomeusz \& Tanewski, 2006). In this context, the following hypothesis is assumed:

H3. Dividends are positively affected by the board size in listed firms from Brazil and Chile.

Another factor that has been associated to the board effectiveness is the board duality, which occurs when the same person hold the roles of both the Chairman of the Board (COB) and the Chief Executive Officer position (CEO). Some studies argue that having the same person for both positions increase the knowledge and commitment with the firm (Boyd, 1995). On the other hand, the opponents affirm that giving too much power to one person may create problem in monitoring and controlling the decision-making process (Bozec \& Dia, 2007). According to Chen et al. (2005), COB-CEO duality is a practice commonly adopted by family firms, promoting an entrenchment behavior from controlling shareholders, which may negatively impact financial performance and dividends distribution. There is some research that concludes that the role of duality 
has no particular effect on performance (Dalton et al., 1998). In the context of Latin America, the board duality may influence negatively the dividend policy, as the ownership concentration is high and the weakness on the institutional framework may motivate to the expropriation of minority shareholders. In this sense, the hypothesis proposed is:

H4. Dividends are negatively affected by the role of board duality in listed firms from Brazil and Chile.

The agency theory affirms that diversity on the board may help to mitigate agency problems and solve conflicts of interests between managers and shareholders (Jurkus et al., 2011). Female directors tend to change the boardroom dynamics and increase the monitoring function compared to male directors, which might provide different perspectives to board discussions, thereby improving the information set available to the board (Adams \& Ferreira, 2004; Gul et al., 2011; Huse \& Solberg, 2006). According to Carter et al. (2014) and Hartojo et al. (2015), women on the board are more risk-averse, more conservative, and less overconfident in their decision-making, which may conduct to increase the distribution of dividends.

Female directors are more likely to engage in monitoring over managers by supervising board duties, and participating on the auditing, nomination and corporate governance committees (Chen et al., 2017). Consequently, agency costs are reduced by demanding corporate governance mechanisms such as dividends (Adams \& Ferreira, 2009; Carter et al., 2010; Francoeur et al., 2008). The representation of women on the board promote higher dividends, since it may alleviate agency costs and the opportunistic behavior of management, thus, larger dividends reduce a possible overinvestment and improve monitoring of capital markets (Pucheta-Martínez et al., 2016). In this vein, Chen et al. (2017) found that board gender composition significantly increases the dividend payout only for firms with weak governance, suggesting that female members use dividends as substitute governance mechanism. Linking the recently evidence of the monitoring role of female directors over financial performance, the female directors will demand more control mechanisms with which to exercise greater supervision and monitoring, making better decisions that favor minority shareholders. In this sense, we hypothesize:

H5. Dividends are positively affected by the percentage of women on the board in listed firms from Brazil and Chile.

\section{Data Sources, Sample Selection and Methodology}

\subsection{Data sources and sample selection}

The study covers the 68 and 40 companies that belong to the most important stock indexes in Brazil and Chile (BMEFBOVESPA and IPSA, respectively) for the years 2004-2014. 18 firms in the banking and insurance sectors were excluded because these are more strictly regulated firms and are subject to greater scrutiny by legal institutions. Another 9 firms were dropped from the sample due to the lack of financial and board composition data from either the firm's annual reports or from Compustat database. The final sample is composed by 49 Brazilian and 32 Chilean companies, which account for almost 70 per cent of the trading volume for stocks in these countries. The final sample is composed by 853 observations. Information related to board composition and family element variables was handle collected from the annual reports of each company. Data on dividends and other financial variables were obtained from Compustat Database.

Table 1 shows the distribution of the firm-year observations across the nine industries and for each country. The sample is classified according to the Industry Classification Benchmark (ICB). The percentage ranges from a low of $0 \%$ in Technology and Oil \& Gas in Chile to a high of $32.3 \%$ in Consumer Goods for Chile. Chile has the smallest number of firm-years (337), accounting for 39.5\% of the whole sample, whereas Brazil has the largest firm-years (516) and accounts for $60.5 \%$ of the study sample. Finally, the two industries with the highest percentages of firm-year observations are Consumer Goods and Utilities for both countries.

Table 1. Sample distribution and summary statistics

\begin{tabular}{lccccc} 
& \multicolumn{6}{c}{$\begin{array}{c}\text { Brazil } \\
\text { Year }\end{array}$} & $\begin{array}{c}\text { Brazil } \\
(\mathrm{N})\end{array}$ & $\begin{array}{c}\text { Chile } \\
(\%)\end{array}$ & $\begin{array}{c}\text { Chile } \\
(\mathrm{N})\end{array}$ & $\begin{array}{c}\text { Total } \\
\text { Basic materials }\end{array}$ & 98 & 19.0 & 55 & 16.3 & 153 \\
Industrial & 78 & 15.1 & 53 & 15.7 & 131 \\
Consumer goods & 111 & 21.5 & 109 & 32.3 & 220 \\
Consumer services & 33 & 6.4 & 22 & 6.5 & 55 \\
Telecommunications & 33 & 6.4 & 11 & 3.3 & 44 \\
Utilities & 99 & 19.2 & 65 & 19.3 & 164 \\
Financial & 33 & 6.4 & 22 & 6.5 & 55 \\
Technology & 11 & 2.1 & 0 & 0.0 & 11 \\
Oil \& gas & 20 & 3.9 & 0 & 0.0 & 20 \\
Total & $\mathbf{5 1 6}$ & $\mathbf{1 0 0 . 0}$ & $\mathbf{3 3 7}$ & $\mathbf{1 0 0 . 0}$ & $\mathbf{8 5 3}$
\end{tabular}

3.2. Variables of study and empirical model The study utilises a panel data study methodology as it provides more robust information, more variability, less collinearity among variables, 
more degrees of freedom and more efficiency (Baltagi, 1995). It also allows us to control for unobserved firm heterogeneity (Setia-Atmaja, 2010). The dividend policy (dependent variable) is represented by two variables. The first measure is a firm's dividend to earnings ratio $(D / E)$. In a given year $t$, we compute a firm's $D / E$ ratio using the firm's annual dividend per share (DPS) divided by its earnings per share (EPS). The second measure is a firm's five-year average $D / E$ ratio, D/E 5yr-avg, from year $t-4$ to the current year $t$. The latter measure reduces the possible fluctuation in dividend payments (Anderson \& Reeb, 2003).

Independent variables are related to the family element and the structure of the board. This study defines family firms as those in which the founding family or family members controlled $20 \%$ or more equity, and was involved in the top management of the firm (La Porta et al., 1999). The family nature of the firm is measured through two dummy variables: 1) A dummy variable that takes a value of 1 if the family controlling shareholder owns at least $20 \%$ of the firm's shares either directly or indirectly through cross-holding or pyramid ownership structure and 0 otherwise (FAMFIRM1) (Claessens et al., 2000; La Porta et al., 1999); 2) a dummy variable that takes a value of 1 if the CEO is a founding member of the firm or the CEO has a family tie with the controlling family shareholder (spouse, child, sibling, or parent), and 0 otherwise (Kang \& Kim, 2016; Yang, 2010).

Board director's composition is measured by four variables: 1) Board size is the total number of directors sitting on the board (BOARDSIZE); 2) board independence is measured as the number of independent directors divided by board size (INDEPENDENCE); 3) COB-CEO duality is an indicator variable equal to one if the CEO is the chairman of the board, and zero otherwise (DUALITY); 4) gender on the board is measured as the number of female directors divided by board size (GENDER) (Chen et al., 2017; Setia-Atmaja, 2010). A group of control variables (Control) is included in our empirical model, which include: ownership concentration $(O C)$, ROA, leverage (LEV), firm age (AGE), and company size (LNASSETS).

To provide empirical testing to the hypotheses addressed in the study, the following two models are developed. The subscripts $i$ and $t$ represent firm and year respectively and $\mu$ the error term:

\section{Results and Discussion}

\subsection{Descriptive analysis}

Table 2 reports summary statistics for the dependent and explanatory variables used in this study. Panel A reports differences in dividends, board composition and control variables between Brazil and Chile. There are consistently significant differences (the most of them at the 1\% level) between the two groups. For instance, the mean (median) values of $D / E(\%)$ ratio are $35.85 \%(28.69 \%)$ and $40.42 \%(39.80 \%)$ for Brazil and Chile, respectively. The mean (median) values of D/E (\%) 5yr-avg ratio are $45.54 \%$ (38.02\%) and $44.36 \%(41.26 \%)$ for Brazil and Chile, respectively. These differences are significant at the 0.01 levels. These results suggest that Chile pays out more dividends than Brazil, which could be explained by the stronger regulatory framework, that protect the minority shareholders rights. Results evidence significant differences in the family dimension and board composition variables. For instance, $57.6 \%$ of listed companies in Brazil are family owned firms, compared to Chile that accounts $72.1 \%$. With respect to family CEO firms there are no significant differences between both countries, therefore, Brazil shows $22.7 \%$ of family CEOs companies and Chile accounts for $22.0 \%$. With respect to board composition, Brazil adopts larger boards (mean of 9 members) compared to Chile (mean of 8 members). The independence of the board is higher in Brazil (0.31) compared to Chile (0.28). The duality COB-CEO practice adopted by listed companies in Brazil is higher (17.8\%) with respect to Chile (3.3\%). Finally, the representation of women on the board is low for both countries: $6 \%$ in Brazil and 3\% in Chile. In a nutshell, Brazil promotes higher gender diversity on the board. Among the corporate variables, the main differences exist in ROA and firm age, between Brazil and Chile subsamples. The ownership concentration ratio is similar for both countries $(0.53$ for Brazil and 0.57 for Chile). Larger companies are from Brazil and older companies are from Chile. Panel B of Table 2 reports differences in study variables between family and non-family firms. We observe that family firms reports lower dividends ratios compared with nonfamily firms $(p=0.01)$. Family firms hire family CEOs $(35.4 \%)$ and have smaller boards compared to non-family firms. Family firms also have the same proportion of independent directors than non-family firms (0.30). In the same vein, family firms

$$
\begin{aligned}
& D / E_{i, t}(\%)=a_{0}+a_{1} \text { Family }_{i, t}+a_{2-14}(\text { BoardComp })+a_{3-14}(\text { Control Vars. })+\mu_{i, t^{*}} \\
& D / E(\%)\left(5 y r-A v g_{i, t}\right)=a_{0}+a_{1} \text { Family }_{i, t}+a_{2-14}(\text { BoardComp })+a_{3-14}(\text { Control Vars. })+\mu_{i, t^{*}}
\end{aligned}
$$


adopt in a greater extent the duality COB-CEO practice $(15.2 \%$ vs $6.7 \%)$, while the ownership concentration is higher in family firms $(0.55$ vs 0.52 ). The more profitable companies are nonfamily firms $(0.08$ vs 0.06$)$. The female on the board accounts the same percentage between both groups of companies. The univariate anal- ysis indicates that several variables differ significantly between family and non-family firms. That is, family CEOs participation, duality COBCEO and ownership concentration are significantly higher in family than in non-family firms, while, dividends, board size, ROA and leverage, are smaller in family firms.

Table 2. Summary statistics of study variables

Panel A: Summary statistics of whole sample, Brazilian firm and Chilean firm subsamples

\begin{tabular}{|c|c|c|c|c|c|c|c|}
\hline \multirow[b]{2}{*}{ Dependent variables } & \multicolumn{2}{|c|}{$\begin{array}{l}\text { Full sample } \\
\qquad(\mathrm{N}=853)\end{array}$} & \multicolumn{2}{|c|}{$\begin{array}{c}\text { Brazil } \\
(n=516)\end{array}$} & \multicolumn{2}{|c|}{$\begin{array}{c}\text { Chile } \\
(\mathrm{n}=337)\end{array}$} & \multirow{2}{*}{$\begin{array}{c}\text { Difference } \\
\text { (in mean) } \\
\text { t-stat }\end{array}$} \\
\hline & Mean & Median & Mean & Median & Mean & Median & \\
\hline D/E (\%) & 37.82 & 34.48 & 35.85 & 28.69 & 40.42 & 39.80 & $2.27^{* * *}$ \\
\hline D/E (\%) 5yr-Avg & 45.05 & 40.04 & 45.54 & 38.02 & 44.36 & 41.26 & $-0.59^{* * * *}$ \\
\hline \multicolumn{8}{|l|}{ Independent variables } \\
\hline Family firm (ownership control) \% & $63.3 \%$ & & $57.6 \%$ & & $72.1 \%$ & & $4.35^{* * *}$ \\
\hline Family CEO firm & $22.4 \%$ & & $22.7 \%$ & & $22.0 \%$ & & -0.24 \\
\hline Board size & 9 & 9 & 9 & 9 & 8 & 7 & $-7.85^{*+* *}$ \\
\hline Board independence & 0.30 & 0.27 & 0.31 & 0.27 & 0.28 & 0.27 & $-1.76^{*}$ \\
\hline Duality COB-CEO & 12.1 & & $17.8 \%$ & & $3.3 \%$ & & $-6.53^{*+*}$ \\
\hline Female on the board & 0.05 & 0.00 & 0.06 & 0.00 & 0.03 & 0.00 & $-6.63^{* * * t}$ \\
\hline Ownership concentration $(\mathrm{OC})$ & 0.54 & 0.54 & 0.53 & 0.52 & 0.57 & 0.57 & 3.43 \\
\hline ROA & 0.07 & 0.06 & 0.07 & 0.05 & 0.07 & 0.07 & $20.74^{* * *}$ \\
\hline Firm size (Ln total assets) & 8.43 & 8.50 & 8.75 & 8.82 & 7.95 & 7.85 & -8.42 \\
\hline Leverage & 35.88 & 39.56 & 0.34 & 0.43 & 0.39 & 0.38 & 0.45 \\
\hline Firm age & 35.16 & 31.00 & 28.60 & 27.50 & 45.21 & 35.0 & $8.84^{* * *}$ \\
\hline
\end{tabular}

Panel B: Summary statistics of whole sample, family vs nonfamily firm subsamples

\begin{tabular}{|c|c|c|c|c|c|c|c|}
\hline \multirow[b]{2}{*}{ Dependent variables } & \multicolumn{2}{|c|}{$\begin{array}{l}\text { Full sample } \\
\qquad(\mathrm{N}=853)\end{array}$} & \multicolumn{2}{|c|}{$\begin{array}{l}\text { Family } \\
(n=540)\end{array}$} & \multicolumn{2}{|c|}{$\begin{array}{l}\text { Nonfamily } \\
(n=313)\end{array}$} & \multirow{2}{*}{$\begin{array}{c}\text { Difference } \\
\text { (in mean) } \\
\text { t-stat }\end{array}$} \\
\hline & Mean & Median & Mean & Median & Mean & Median & \\
\hline D/E (\%) & 37.82 & 34.48 & 35.45 & 32.79 & 42.53 & 39.39 & $-3.39^{* * * *}$ \\
\hline D/E (\%) 5yr-Avg & 45.05 & 40.04 & 42.89 & 39.36 & 48.49 & 44.11 & $-2.80^{* * *}$ \\
\hline \multicolumn{8}{|l|}{ Independent variables } \\
\hline Family CEO firm & $22.4 \%$ & & $35.4 \%$ & & $0 \%$ & & $13.07^{* * *}$ \\
\hline Board size & 9 & 9 & 8 & 8 & 9 & 9 & $-8.03^{* * * *}$ \\
\hline Board independence & 0.30 & 0.27 & 0.30 & 0.27 & 0.30 & 0.22 & $-0.04^{* * * *}$ \\
\hline Duality COB-CEO & 12.1 & & $15.2 \%$ & & $6.7 \%$ & & $3.69^{* * *}$ \\
\hline Female on the board & 0.05 & 0.00 & 0.05 & 0.00 & 0.05 & 0.00 & $-0.03^{*}$ \\
\hline Ownership concentration $(\mathrm{OC})$ & 0.54 & 0.54 & 0.55 & 0.55 & 0.52 & 0.53 & $2.91^{* * * *}$ \\
\hline ROA & 0.07 & 0.06 & 0.06 & 0.05 & 0.08 & 0.06 & -3.98 \\
\hline Firm size (Ln total assets) & 8.43 & 8.50 & 8.17 & 8.17 & 8.89 & 8.91 & -7.39 \\
\hline Leverage & 35.88 & 39.56 & 0.36 & 0.42 & 0.37 & 0.36 & -0.09 \\
\hline
\end{tabular}

Pooled t-tests are conducted to compare the difference in the mean values of all variables between countries and family variable. ${ }^{* * *},{ }^{* *},{ }^{*}$ indicate significance at the $1 \%, 5 \%$, and $10 \%$ levels, respectively. 


\subsection{Correlation analysis}

A correlation analysis was conducted to analyse possible multicollinearity problems between the study variables. Table 3 shows that firms controlled by family members and family-CEO firms are negatively related to dividends. As per our expectation, board size and female on the board are positively related to dividends ratios, while duality in the board has a negative effect on dividends. Corporate characteristics such as ROA, size and leverage conduct to an increase on dividends. We test the variance inflation factors (VIFs), and results exclude the presence of multicollinearity among independent variables. as a dependent variable. Results indicate that family firms motivates to higher dividends (columns 1 and 5) at a 0.01 significance level. Thus, $\mathrm{H} 1$ is partially accepted, since is significant when board composition and firm characteristics are introduced in the models (column 5). With respect to the board composition, empirical evidence shows that larger boards (columns 4 and 6) and the women participation on the board (columns 3 to 6) have a significant and positive influence on the dividend payout, which leads to accept the $\mathrm{H} 3$ and $\mathrm{H} 5$. Those more profitable and older companies account higher dividends $(p=0.01)$. By contrast, Panel B of table 3 evidences that family

Table 3. Correlation matrix

\begin{tabular}{|c|c|c|c|c|c|c|c|c|c|c|}
\hline & 1 & 2 & 3 & 4 & 5 & 6 & 7 & 8 & 9 & 10 \\
\hline 1. $D / E$ & 1.000 & & & & & & & & & \\
\hline 2. Family firm & $-0.135^{* * *}$ & 1.000 & & & & & & & & \\
\hline 3. Family CEO & $-0.094^{*}$ & $0.409^{* * *}$ & 1.000 & & & & & & & \\
\hline 4. BS & $0.096^{*}$ & $-0.265^{* *}$ & $-0.177^{* *}$ & 1.000 & & & & & & \\
\hline 5. BI & -0.055 & -0.001 & $0.090^{* *}$ & $-0.078^{*}$ & 1.000 & & & & & \\
\hline 6. Duality & $-0.128^{* *}$ & $0.125^{* *}$ & $0.440^{* *}$ & -0.031 & $0.104^{* *}$ & 1.000 & & & & \\
\hline 7. Female & $0.116^{* *}$ & -0.001 & $0.068^{*}$ & 0.039 & -0.067 & -0.061 & 1.000 & & & \\
\hline 8. OC & $0.153^{* \star * *}$ & $0.099^{* *}$ & 0.026 & $-0.097^{\star *}$ & $-0.228^{* *}$ & -0.044 & $0.092^{* *}$ & 1.000 & & \\
\hline 9. $\mathrm{ROA}$ & $0.370^{* *}$ & $-0.135^{* *}$ & -0.053 & -0.005 & 0.013 & -0.005 & -0.037 & $0.139^{* *}$ & 1.000 & \\
\hline 10. Size & $0.091^{*}$ & $-0.245^{* *}$ & -0.046 & $0.277^{* *}$ & $-0.084^{*}$ & $-0.081^{*}$ & $0.188^{* *}$ & 0.016 & $-0.069^{*}$ & 1.000 \\
\hline 11. Leverage & $0.219^{* * *}$ & 0.066 & $-0.077^{*}$ & -0.018 & $0.154^{* *}$ & 0.003 & 0.008 & 0.053 & $0.463^{* *}$ & $-0.164^{* *}$ \\
\hline
\end{tabular}

\subsection{Multivariate analysis}

\subsubsection{OLS Regression analysis}

We start with a basic pooled ordinary least square (OLS) regression to test hypothesis 1 by controlling for both industry and year fixed effects. ${ }^{1}$ The dependent variable is measured by both $D / E_{i, t}(\%)$ and $D / E$ 5yr-Avg $g_{i, t}(\%)$. We are primarily interested in Family Firm variable, which is a dummy variable and takes a value of 1 if firm $i$ is a family firm in year $t$ and 0 otherwise, and board composition variables (size, independence, duality and female). The control variables include firm characteristics.

Table 4 reports the regression results. Columns 1 , 3 and 5 report the regression results using $D / E_{i, t}(\%)$ as a dependent variable, whereas columns 2,4 , and 6 report the results using $D / E(\%) 5 y r-A v g_{i, t}$
CEOs firms inhibit the dividends payout (columns 2, 3, 4 and 6). However the board size and female on the board increase the dividends, which suggest that board composition leads to higher dividend ratios. With regard to control variables, dividend payout ratio is positively associated with ROA, leverage and firm age, and negatively associated with firm size. These results are supported for those obtained by Michiels et al. (2015) which argument that the presence of family governance practices such as dividends or the board composition may alleviate the potential intra familial principal-principal conflicts of interest.

Our study checks for possible multicollinenarity issues and report the mean value and maximum values of Variance Inflation Factor (VIF). All the mean values of VIF are smaller than 10 in all regressions.

\footnotetext{
1. The study performs Hausman test to determine whether fixed effect or random effect model is more appropriate. Results of Hausman test support the acceptance of alternative hypothesis, suggesting that the fixed-effect model fits our database better than the random effect model.
} 
Table 4. Regression of dividend payout

Panel A. Family firm effect on dividend policy

\begin{tabular}{|c|c|c|c|c|c|c|}
\hline & (1) & $(2)$ & (3) & (4) & (5) & (6) \\
\hline Variables & $D / E(\%)$ & $D / E(\%) 5 y r-A v g$ & $D / E(\%)$ & $D / E(\%) 5 y r-A v g$ & $D / E(\%)$ & $D / E(\%) 5 y r-A v g$ \\
\hline Family firm & $\begin{array}{l}5.96^{* *+*} \\
(2.72)\end{array}$ & $\begin{array}{c}1.87 \\
(1.00)\end{array}$ & $\begin{array}{c}0.16 \\
(0.07)\end{array}$ & $\begin{array}{c}1.51 \\
(0.77)\end{array}$ & $\begin{array}{l}5.90^{*+* *} \\
(2.69)\end{array}$ & $\begin{array}{c}2.34 \\
(1.27)\end{array}$ \\
\hline Board size & & & $\begin{array}{c}0.70 \\
(1.27)\end{array}$ & $\begin{array}{l}1.47^{* * *} \\
(2.95)\end{array}$ & $\begin{array}{c}0.48 \\
(0.90)\end{array}$ & $\begin{array}{l}1.62^{* * *} \\
(3.05)\end{array}$ \\
\hline Board independence & & & $\begin{array}{c}-2.27 \\
(-0.45)\end{array}$ & $\begin{array}{l}-0.47 \\
(-0.10)\end{array}$ & $\begin{array}{c}0.54 \\
(0.12)\end{array}$ & $\begin{array}{l}-2.30 \\
(-0.47)\end{array}$ \\
\hline Duality & & & $\begin{array}{l}-3.65 \\
(-1.22)\end{array}$ & $\begin{array}{c}0.64 \\
(0.19)\end{array}$ & $\begin{array}{c}-1.19 \\
(-0.46)\end{array}$ & $\begin{array}{l}1.80 \\
(0.60)\end{array}$ \\
\hline Female on the board & & & $\begin{array}{l}28.22^{4 *} \\
(2.06)\end{array}$ & $\begin{array}{l}27.84^{* *} \\
(2.15)\end{array}$ & $\begin{array}{l}25.14^{* *} \\
(2.01)\end{array}$ & $\begin{array}{l}26.40^{* *} \\
(2.00)\end{array}$ \\
\hline ROA & $\begin{array}{c}124.65^{* * * *} \\
(8.82)\end{array}$ & $\begin{array}{l}85.79^{* * * *} \\
(5.37)\end{array}$ & & & $\begin{array}{c}123.88^{*+* *} \\
(8.97)\end{array}$ & $\begin{array}{l}82.74^{* * * *} \\
(5.37)\end{array}$ \\
\hline Firm size & $\begin{array}{c}0.35 \\
(0.42)\end{array}$ & $\begin{array}{l}-1.95^{* \ldots *} \\
(-2.36)\end{array}$ & & & $\begin{array}{c}-0.10 \\
(-0.12)\end{array}$ & $\begin{array}{l}-2.89^{*+\ldots} \\
(-3.51)\end{array}$ \\
\hline Leverage & $\begin{array}{c}-0.01 \\
(-1.24)\end{array}$ & $\begin{array}{l}0.02^{\prime} \\
(1.79)\end{array}$ & & & $\begin{array}{l}-0.01 \\
(-1.37)\end{array}$ & $\begin{array}{l}0.02^{*} \\
(1.64)\end{array}$ \\
\hline Firm age & $\begin{array}{l}3.86^{*+\ldots} \\
(4.39)\end{array}$ & $\begin{array}{l}4.80^{+3 *} \\
(4.60)\end{array}$ & & & $\begin{array}{l}3.84^{+* n+} \\
(4.28)\end{array}$ & $\begin{array}{l}4.80^{* 3 *} \\
(4.68)\end{array}$ \\
\hline Industry effect & Yes & Yes & Yes & Yes & Yes & Yes \\
\hline Year effect & Yes & Yes & Yes & Yes & Yes & Yes \\
\hline Constant & $\begin{array}{l}-1.25 \\
(-0.17)\end{array}$ & $\begin{array}{l}21.24^{* * * *} \\
(2.54)\end{array}$ & $\begin{array}{l}24.44^{* * * *} \\
(3.74)\end{array}$ & $\begin{array}{l}20.26^{* * *+} \\
(3.05)\end{array}$ & $\begin{array}{l}-2.25 \\
(-0.27)\end{array}$ & $\begin{array}{l}14.67 \\
(1.60)\end{array}$ \\
\hline Hausman test & & & & & & \\
\hline P-value & 0.00 & 0.00 & 0.00 & 0.00 & 0.00 & 0.00 \\
\hline$F$ test $P$-value & 0.00 & 0.00 & 0.00 & 0.00 & 0.00 & 0.00 \\
\hline Adjusted $\mathrm{R}^{2}$ & 0.30 & 0.28 & 0.13 & 0.42 & 0.30 & 0.31 \\
\hline VIF (Average) & 1.77 & 1.85 & 1.70 & 1.78 & 1.72 & 1.80 \\
\hline Observations & 795 & 772 & 798 & 772 & 795 & 772 \\
\hline \multicolumn{7}{|c|}{ Panel B. Family CEO effect on dividend policy } \\
\hline Variables & $\begin{array}{c}(1) \\
D / E(\%)\end{array}$ & $\begin{array}{c}(2) \\
D / E(\%) 5 y r-A v g\end{array}$ & $\begin{array}{c}(3) \\
D / E(\%)\end{array}$ & $\begin{array}{c}(4) \\
D / E(\%) 5 y r-A v g\end{array}$ & $\begin{array}{c}(5) \\
D / E(\%)\end{array}$ & (6) \\
\hline Family CEO & $\begin{array}{l}-1.95 \\
(-1.13)\end{array}$ & $\begin{array}{l}-3.99^{* *} \\
(-2.26)\end{array}$ & $\begin{array}{l}-4.15^{*} \\
(-1.79)\end{array}$ & $\begin{array}{l}-4.27^{* *} \\
(-2.30)\end{array}$ & $\begin{array}{l}-2.18 \\
(-1.09)\end{array}$ & $\begin{array}{l}-3.86 \\
(-2.12)\end{array}$ \\
\hline Board size & & & $\begin{array}{c}0.58 \\
(1.06)\end{array}$ & $\begin{array}{l}1.31^{*+*} \\
(2.61)\end{array}$ & $\begin{array}{l}0.24 \\
(0.45)\end{array}$ & $\begin{array}{l}1.44^{*+*} \\
(2.69)\end{array}$ \\
\hline Board independence & & & $\begin{array}{c}-2.63 \\
(-0.53)\end{array}$ & $\begin{array}{l}-1.15 \\
(-0.24)\end{array}$ & $\begin{array}{l}-2.17 \\
(-0.50)\end{array}$ & $\begin{array}{l}-3.33 \\
(-0.69)\end{array}$ \\
\hline Duality & & & $\begin{array}{l}-1.19 \\
(-0.35)\end{array}$ & $\begin{array}{c}3.04 \\
(0.84)\end{array}$ & $\begin{array}{c}0.91 \\
(0.31)\end{array}$ & $\begin{array}{c}4.02 \\
(1.26)\end{array}$ \\
\hline Female on the board & & & $\begin{array}{l}29.12^{\prime *} \\
(2.15)\end{array}$ & $\begin{array}{l}28.57^{* *} \\
(2.21)\end{array}$ & $\begin{array}{l}28.81^{* *} \\
(2.24)\end{array}$ & $\begin{array}{l}27.40^{* *} \\
(2.06)\end{array}$ \\
\hline ROA & $\begin{array}{c}118.31^{+* *} \\
(8.24)\end{array}$ & $\begin{array}{c}82.74^{* * * *} \\
(5.28)\end{array}$ & & & $\begin{array}{c}117.73^{*+* *} \\
(8.32)\end{array}$ & $\begin{array}{l}79.77^{1} \\
(5.22)\end{array}$ \\
\hline Firm size & $\begin{array}{c}0.17 \\
(0.21)\end{array}$ & $\begin{array}{l}-2.02^{\prime *} \\
(-2.48)\end{array}$ & & & $\begin{array}{c}-0.21 \\
(-0.25)\end{array}$ & $\begin{array}{l}-2.97^{\prime \prime} \\
(-3.69)\end{array}$ \\
\hline Leverage & $\begin{array}{c}-0.00 \\
(-0.85)\end{array}$ & $\begin{array}{l}0.02^{* *} \\
(1.92)\end{array}$ & & & $\begin{array}{c}-0.01 \\
(-1.08)\end{array}$ & $\begin{array}{l}0.02^{*} \\
(1.73)\end{array}$ \\
\hline Firm age & $\begin{array}{l}3.67^{* * *} \\
(4.12)\end{array}$ & $\begin{array}{l}4.84^{+41} \\
(4.68)\end{array}$ & & & $\begin{array}{l}3.77^{+* 1} \\
(4.19)\end{array}$ & $\begin{array}{l}4.90 \\
(4.80)\end{array}$ \\
\hline Industry effect & Yes & Yes & Yes & Yes & Yes & Yes \\
\hline Year effect & Yes & Yes & Yes & Yes & Yes & Yes \\
\hline Constant & $\begin{array}{c}5.75 \\
(0.81)\end{array}$ & $\begin{array}{c}23.75^{5 * *} \\
(2.93)\end{array}$ & $\begin{array}{c}25.64^{* * * *} \\
(4.64)\end{array}$ & $\begin{array}{c}22.98^{* * * *} \\
(3.63)\end{array}$ & $\begin{array}{l}6.25 \\
(0.79)\end{array}$ & $\begin{array}{l}18.57^{* *} \\
(2.12)\end{array}$ \\
\hline Hausman test & & & & & & \\
\hline P-value & 0.00 & 0.00 & 0.00 & 0.00 & 0.00 & 0.00 \\
\hline$F$ test $P$-value & 0.00 & 0.00 & 0.00 & 0.00 & 0.00 & 0.00 \\
\hline Adjusted $\mathrm{R}^{2}$ & 0.29 & 0.29 & 0.14 & 0.42 & 0.30 & 0.31 \\
\hline VIF (Average) & 1.74 & 1.81 & 1.70 & 1.76 & 1.71 & 1.78 \\
\hline Observations & 795 & 772 & 798 & 772 & 795 & 772 \\
\hline
\end{tabular}

This table reports pooled OLS regression results using Huber-White method for standard errors. The numbers reported in parentheses are regression t-statistics. ${ }^{* * *},{ }^{* *},{ }^{*}$ indicate significance at the $1 \%, 5 \%$, and $10 \%$ levels, respectively. 


\subsubsection{Logit regression analysis}

The study conducts Logit regressions to provide additional evidence on the relationship between family firm (family CEO firm) and dividend ratios and attends possible data noise of the $D / E$ ratios. The dependent variable High Dividend $_{i, t}$ takes a value of 1 if firm $i$ 's dividend payout is greater than the median value of the respective dividend measure $\left(D / E_{i, t}\right.$ or $D / E$ 5yr- $\left.A v g_{i, t}\right)$ in year $t$ and 0 otherwise. The Logit regression is similar to the OLS regression equation. ( 1 and 2 ) and it is specified below: ticipation on the board) motivate to higher dividends ratios, while the COB-CEO duality has a negative effect. In this sense, the $\mathrm{H} 1, \mathrm{H} 3$ and $\mathrm{H} 5$ are accepted. Among the firm characteristics variables, ROA and Firm Age are positively related to high dividend payout. In Panel B of Table 5 , results demonstrate that family CEO firms inhibit dividends while the size, independence, and female on the board increase dividend ratios. By contrast, duality COB-CEO decreases dividends, which leads to accept the H4. Results confirm that ROA and firm age promotes higher

$$
\text { High dividend } \left.{ }_{i, t}=a_{0}+a_{1} \text { Family }_{i, t}+a_{2-14}(\text { BoardComp })+a_{3-14} \text { (Control Vars. }\right)+\mu_{i, t^{*}}
$$

Columns 1, 3, and 5 of Table 5 (Panel A) show that the dependent variable High Dividend $_{i, t}$ is determined by the firm's $D / E_{i, t}$ ratio, whereas in columns 2,4 , and 6 , it is determined by the firm's D/E $5 y r-A v g_{i, t}$ ratio. High Dividend ${ }_{i, t}$ variable is based in the median value of dividend payout in firm i's industry. Thus, High Dividend takes a value of 1 if firm i's dividend payout is greater than the median value of the respective dividend measure $\left(D / E(\%)_{i, t}\right.$ or $\left.D / E(\%) 5 y r-A v g_{i, t}\right)$ in firm i's industry in year $t$ and 0 otherwise. Obtained results are consistent with those reported in Table 4 based on the OLS analysis. Specifically, coefficients on Family Firms have a positive influence on dividends (columns 1, 5 and 6 ) at 0.05 and 0.10 significant levels. The board composition (board size and female par- dividends. Results suggest that family ownership participation has a positive significant influence on dividend payout, while their participation on CEO position has a contrary effect, and the board composition play a strategic role on the relationship. These results confirm that dividend policy and corporate governance mechanisms increase the credibility in capital markets. According to La Porta et al. (2000), dividends can be considered as substitutes (substitute hypothesis) or outcomes (outcome hypothesis) of corporate governance mechanisms. Our results support the outcome hypothesis; therefore, we can consider dividend payouts and board composition as instruments to alleviate potential intrafamilial conflicts of interest between controlling and minority shareholders.

Table 5. Logit regression of dividend payout

Panel A. Family firm effect on dividend policy

Variables

Family firm

Board size

Board independence

Duality

Female on the board

$\begin{array}{lcc}\text { ROA } & 8.62^{* * *+} & 4.59^{* * * *} \\ & (4.91) & (2.96) \\ \text { Firm size } & -0.05 & -0.31^{* * * *} \\ & (-0.56) & (-3.13) \\ \text { Leverage } & -0.00^{* *} & 0.00 \\ & (-2.14) & (0.38) \\ \text { Firm age } & 0.62^{* * *} & 0.94^{* * *} \\ & (5.69) & (6.61) \\ \text { Industry effect } & \text { Yes } & \text { Yes }\end{array}$

(1)

(3)

D/E (\%)

$0.50^{* *}$

(2.17)

0.14
$(0.59)$

D/E (\%)

0.12

(0.56)

0.04

$(0.87)$

0.10

(0.23)

$-0.72^{\cdots+*}$

$(-2.81)$

1.15

(1.00)

$4.59^{* * *}$

$-0.31^{* * *}$

$(-3.13)$

$(0.38)$

(6.61)
(4)

D/E (\%) 5yr-Avg

0.14

$(0.62)$

$0.13^{* * * *}$

(2.41)

0.43

$(0.87)$

$-0.40$

$(-1.18)$

1.87

(1.44)
(5)

D/E (\%)

$0.51^{*}$

(1.83)

0.04

(0.83)

$1.22^{* *}$

(2.18)

$-0.74^{*+* * *}$

$(-2.41)$

2.29

(1.67)

$10.37^{* * *}$

(5.78)

0.13

(1.37)

0.00

(0.19)

$0.68^{\text {*t* }}$

(5.81)

Yes
(6)

D/E (\%) 5yr-Avg

$0.48^{* *}$

(1.92)

$0.13^{* * *+}$

(2.41)

0.27

(0.51)

$-0.33$

$(-1.01)$

0.04

(0.03)

$5.86^{4 * *+}$

(3.99)

$-0.11$

$(-1.15)$

0.00

(0.18)

$0.22^{*}$

(1.79) 


\begin{tabular}{|c|c|c|c|c|c|c|}
\hline Year effect & No & No & No & No & No & No \\
\hline \multirow[t]{2}{*}{ Constant } & $-2.48^{* * *}$ & -1.01 & -0.01 & -0.79 & $-4.84^{* * *}$ & -1.52 \\
\hline & $(-3.08)$ & $(-1.10)$ & $(-0.02)$ & $(-1.14)$ & $(-4.99)$ & $(-1.50)$ \\
\hline \multicolumn{7}{|l|}{ Hausman test } \\
\hline P-value & 0.00 & 0.00 & 0.00 & 0.00 & 0.00 & 0.00 \\
\hline $\mathrm{F}$ test $\mathrm{P}$-value & 0.00 & 0.00 & 0.00 & 0.00 & 0.00 & 0.00 \\
\hline Adjusted $\mathrm{R}^{2}$ & 0.16 & 0.19 & 0.05 & 0.10 & 0.22 & 0.12 \\
\hline Observations & 795 & 772 & 798 & 772 & 795 & 772 \\
\hline \multicolumn{7}{|c|}{ Panel B. Family firm CEO effect on dividend policy } \\
\hline & (1) & (2) & (3) & (4) & (5) & (6) \\
\hline Variables & $D / E(\%)$ & $D / E(\%) 5 y r-A v g$ & $D / E(\%)$ & $D / E(\%) 5 y r-A v g$ & $D / E(\%)$ & $D / E(\%) 5 y r-A v g$ \\
\hline \multirow[t]{2}{*}{ Family CEO } & $-0.07^{* *}$ & $-0.53^{* *}$ & -0.03 & $-0.51^{*}$ & 0.18 & $-0.45^{*}$ \\
\hline & $(-0.33)$ & $(-2.19)$ & $(-0.12)$ & $(-1.88)$ & $(0.66)$ & $(-1.63)$ \\
\hline \multirow[t]{2}{*}{ Board size } & & & $0.08^{*}$ & $0.11^{* *}$ & 0.03 & $0.10^{*}$ \\
\hline & & & $(1.67)$ & $(2.14)$ & $(0.66)$ & $(1.85)$ \\
\hline \multirow[t]{2}{*}{ Board independence } & & & $0.74^{*}$ & 0.18 & $0.95^{*}$ & 0.00 \\
\hline & & & $(1.60)$ & $(0.36)$ & (1.79) & $(0.00)$ \\
\hline \multirow[t]{2}{*}{ Duality } & & & $-0.77^{* * *}$ & -0.08 & $-0.78^{* *}$ & -0.01 \\
\hline & & & $(-2.52)$ & $(-0.23)$ & $(-2.29)$ & $(-0.02)$ \\
\hline \multirow[t]{2}{*}{ Female on the board } & & & $2.21^{*}$ & -0.17 & $2.58^{* *}$ & 0.29 \\
\hline & & & $(1.86)$ & $(-0.15)$ & $(1.90)$ & $(0.23)$ \\
\hline \multirow[t]{2}{*}{ ROA } & $9.76^{* * *}$ & $5.58^{* * *}$ & & & $10.12^{* * *}$ & $5.36^{* * *}$ \\
\hline & (5.29) & $(3.78)$ & & & $(5.46)$ & (3.59) \\
\hline \multirow[t]{2}{*}{ Firm size } & 0.15 & -0.06 & & & 0.12 & -0.12 \\
\hline & $(1.57)$ & $(-0.66)$ & & & $(1.21)$ & $(-1.20)$ \\
\hline \multirow[t]{2}{*}{ Leverage } & 0.00 & 0.00 & & & 0.00 & 0.00 \\
\hline & $(0.55)$ & $(0.29)$ & & & $(0.38)$ & $(0.36)$ \\
\hline \multirow[t]{2}{*}{ Firm age } & $0.68^{* * *}$ & $0.23^{*}$ & & & $0.69^{* * *}$ & $0.22^{*}$ \\
\hline & $(5.80)$ & $(1.88)$ & & & $(5.84)$ & $(1.82)$ \\
\hline Industry effect & Yes & Yes & Yes & Yes & Yes & Yes \\
\hline Year effect & Yes & No & No & No & No & No \\
\hline \multirow[t]{2}{*}{ Constant } & $-3.87^{* * *}$ & -0.43 & -0.25 & -0.46 & $-4.18^{* * * t}$ & -0.76 \\
\hline & $(-4.43)$ & $(-0.45)$ & $(-0.43)$ & $(-0.73)$ & $(-4.52)$ & $(-0.77)$ \\
\hline \multicolumn{7}{|l|}{ Hausman test } \\
\hline P-value & 0.00 & 0.00 & 0.00 & 0.00 & 0.00 & 0.00 \\
\hline $\mathrm{F}$ test $\mathrm{P}$-value & 0.00 & 0.00 & 0.00 & 0.00 & 0.00 & 0.00 \\
\hline Adjusted $\mathrm{R}^{2}$ & 0.21 & 0.11 & 0.08 & 0.09 & 0.22 & 0.12 \\
\hline Observations & 795 & 772 & 798 & 772 & 795 & 772 \\
\hline
\end{tabular}

This table reports pooled Logit regression results using Huber-White method for standard errors. The numbers reported in parentheses are regression Z-statistics. ${ }^{* * *},{ }^{* *},{ }^{*}$ indicate significance at the $1 \%, 5 \%$, and $10 \%$ levels, respectively.

\subsubsection{Additional robustness tests}

Prior results show that family dimension influences on the dividend policy. On the one hand, the family participation on the ownership motivates to increase dividends, while the Family CEO firms decrease dividend payouts in contexts characterized by principal-principal agency problems such as Latin America. On the other hand, the board composition plays a strategic role, since the size and female on the board increase dividends. These results suggest that corporate governance dimensions and dividend policy are complementary mechanisms and aim to increase the shareholders' confidence. In this way, the table 6 shows an additional robustness test (OLS regression) to analyze if a corporate governance compliance index composed by the structure and functioning of the board, ownership structure and General Assembly, ethics and conflict of interest and other information related to corporate governance, moderates the relation between the family element and dividend payout. Results indicate a positive moderator effect of corporate governance on the relationship between Family CEO firms and dividends. By contrast there is no effect on the relationship between corporate governance index and the relationship between Family Firms and dividend policy. Results described on table 6 confirm that corporate governance mechanisms favor the dividends payouts on weak institutional frameworks. 
Table 6. Regression of dividend payout: Effect of the corporate governance transparency index

Panel A. Family firm and CGTI effect on dividend policy

Variables

Family firm

CGTI

Family firm*CGTI

ROA

Firm size

Leverage

Firm age

Industry effect

Year effect

Constant

Hausman test

$P$-value

$\mathrm{F}$ test $\mathrm{P}$-value

Adjusted $\mathrm{R}^{2}$

VIF (Max)

VIF (Average)

Observations

Panel B. Family CEO and CGTI effect on dividend policy

$5.93^{* * *+}$

(2.72)

$(0.22)$

$124.40^{* * * *}$

$(8.77)$

0.28

$(0.32)$

$-0.01$

$(-1.22)$

$3.83^{\text {*****+*}}$

(4.35)

$-1.42$

$(-16.41)$

D/E (\%)

$-2.01$

$(-1.15)$

(0.42)

Family CEO*CGTI

ROA

$117.87^{* * *}$

(8.16)

Firm size

(0.05)

Leverage

Firm age

Industry effect

Year effect

Constant

$-0.00$

$(-0.82)$

$3.61^{\text {t*t* }}$

(4.05)

(0.75)

Hausman test

$\mathrm{P}$-value

$\mathrm{F}$ test $\mathrm{P}$-value

Adjusted $\mathrm{R}^{2}$

VIF (Max)

VIF (Average)

Observations
(1)

1.74

Yes

Yes

0.00

0.00

0.30

2.64

1.85

795

(1)

3.42

0.04

Yes

Yes

5.34

$D / E(\%) 5 y r-A v g$
1.64
$(0.88)$
11.92
$(1.26)$

$84.17^{* * *}$

$D / E$ (\%) $5 y r-A v g$

0.00

0.00

0.29

2.64

1.82

795
(2)

(5.19)

$-2.39^{* * *}$

$(-2.68)$

0.02

(1.86)

$4.58^{* * * *}$

(4.36)

Yes

Yes

20.30 "*

(2.38)

0.00

0.00

0.28

3.18

1.96

772

(2)

$-4.21$

$(-2.44)$

13.25

(1.39)

(3)

D/E (\%)

13.85

(1.59)

10.06

(0.76)

$-12.51$

$(-0.93)$

$124.56^{\text {tw* }}$

(8.83)

0.26

(0.30)

$-0.01$

$(-1.18)$

$3.73^{* * *}$

(4.26)

Yes

Yes

$-6.03$

$(-0.61)$

0.00

0.00

0.13

20.05

3.47

798

(3)

D/E (\%)

$-4.45^{* *}$

(-2.28)

$-4.19$

$(-0.51)$

$10.16{ }^{* * *}$

(2.80)

$123.22^{* * * *}$

(8.59)

0.41

(0.47)

$-0.01$

$(-1.12)$

$3.72^{* * *+}$

(4.17)

Yes

Yes

1.76

(0.24)

(2.70)

0.00

0.00

0.29

3.18

1.92

772

0.00
(4)

D/E (\%) 5yr-Avg

$-11.36$

$(-1.13)$

0.80

(0.06)

20.10

(1.31)

$82.31^{\text {t*** }}$

(5.11)

$-2.36^{* * * *}$

$(-2.60)$

0.02

(1.73)

$4.82^{* * *}$

(4.54)

Yes

Yes

$26.65^{* * * *}$

(2.67)

0.00

0.00

0.29

23.21

3.75

772

(4)

D/E (\%) 5yr-Avg

$-5.99^{* * * *}$

$(-3.13)$

8.72

(0.90)

$6.72^{* *}$

(2.19)

$84.81^{* * *+}$

(5.21)

$-2.09^{* *}$

$(-2.28)$

$0.02 *$

(1.86)

$4.63^{* * *+}$

(4.39)

Yes

Yes

$18.81^{\text {** }}$

(2.25)

0.00

0.00

0.29

3.18

1.95

772

This table reports pooled OLS regression results using Huber-White method for standard errors. The numbers reported in parentheses are regression t-statistics. ${ }^{* * *},{ }^{* *},{ }^{*}$ indicate significance at the $1 \%, 5 \%$, and $10 \%$ levels, respectively. 


\section{Conclusions and Future Research}

This paper investigated the influence of family element and board composition on dividend policy in two countries characterized by mandatory dividend laws and weakness on their institutional framework. Specifically, the study tested the argument that family firms tend to increase dividends as response of mitigating the family' expropriation of minority shareholders' wealth, also known as the intra-familial principal-principal conflict of interest between active and passive family shareholders. A fixed effect panel data analysis was conducted to analyze if the family dimension of listed firms in Brazil and Chile leads to higher dividend payout ratios. Results indicate that the involvement of the family in the ownership increase dividends. By contrast, the presence of family members on the CEO position reduces dividends. This suggests that in the Brazilian and Chilean cases, family firms reduce the expropriation of minority shareholders' wealth via paying dividends. These results are supported for those obtained by Michiels et al. (2015), who argument that the presence of family governance practices such as dividends or the board composition may alleviate the potential intra familial principal-principal conflicts of interest.

With respect to the board composition, we confirm that some of their dimensions such as size and gender on the board may balance the family's power between family and outside investors (Setia-Atmaja, 2010). These positive relations indicate that board composition and dividends are complementary mechanisms to diminish the agency problem principal-principal, especially in countries characterized by a higher ownership concentration and a lower legal protection framework to passive shareholders. According to La Porta et al. (2000), dividends can be considered as substitutes (substitute hypothesis) or outcomes (outcome hypothesis) of corporate governance mechanisms. Our results support the outcome hypothesis; therefore, we can consider dividend payouts and board composition as instruments to alleviate potential intra-familial conflicts of interest between controlling and minority shareholders.

We conduct additional tests to confirm if corporate governance mechanisms influence on the dividend policy, introducing a corporate governance compliance index. Results suggest that the corporate governance index increase dividends when a family member occupies the CEO position. Our results are consistent with the notion that independent directors enhance the corporate governance role in firms where the institutional system is less effective (An- derson \& Reeb, 2004; Gomez-Mejia \& LarrazaKintana, 2003).

This paper provides several important theoretical and practical contributions to the literature. First, the study demonstrated that dividends constitute a complementary corporate governance mechanism to avoid the principal-principal agent conflict (Agency problem Type II) in countries characterized by higher levels of ownership concentration. Secondly, the structure of the board is a key variable to increase (decrease) dividends in family listed firms. For policy makers and those responsible to manage family firms, findings of this study could serve to justify initiatives to encourage more independent and female presence on the board of directors, especially in family controlled firms.

Finally, our study also has some limitations that provide challenges for future research. Although our database contains important family firm variables and the board composition, it does not contain other variables such as the generational stage, detailed information on ownership structure, or CEOs characteristics. These additional variables would allow us to more thoroughly test relations between these variables and dividend policy. Furthermore, the study is focused only in two Latin American countries and the period 2004-2014; it would be interesting to see whether similar issues exist in other emerging countries of the region and further years. Finally, further research could integrate another variables such as corporate social responsibility, risk taking or propensity to innovation and development in family firms, and how these variables may impact the dividend policy.

\section{References}

Adams, R. B. \& Ferreira, D. (2004). Gender diversity in the boardroom, European Corporate Governance Institute, Finance Working Paper, 57, 1-30.

Adams, R. B. \& Ferreira, D. (2009). Women in the boardroom and their impact of governance and performance. Journal of Financial Economics, 94(2), 291-309. https://doi.org/10.1016/j.jfineco.2008.10.007

Adjaoud, F. \& Ben-Amar, W. (2010). Corporate governance and dividend policy: Shareholders' protection or expropriation? Journal of Business Finance \& Accounting, 37(5-6), 648-667. https://doi. org/10.1111/j.1468-5957.2010.02192.x

Aguilera, R. V. \& Crespi-Cladera, R. (2012). Firm family firms: Current debates of corporate governance in family firms. Journal of Family Business Strategy, 3(2), 66-69. https://doi.org/10.1016/j. jfbs.2012.03.006

Aivazian, V., Booth, L., \& Cleary, S. (2003). Do emerging market firms follow different dividend policies from US firms? The Journal of Financial Research, 26, 371-87. https://doi.org/10.1111/14756803.00064 
Alias, N., Rahim, R. A., Nor, F. M., \& Yaacob, M. H. (2014). Board structure, capital structure and dividend per share: Is there interaction effect? Indian Journal of Corporate Governance, 7(1), 2-13. https://doi.org/10.1177/0974686220140101

Al-Najjar, B. (2013). The financial determinants of corporate cash holdings: Evidence from some emerging markets. International Business Review, 22, 77-88. https: //doi.org/10.1016/j.ibusrev.2012.02.004

Anderson, R. C. \& Reeb, D. (2003). Founding-family ownership and firm performance: Evidence from the S\&P 500. Journal of Finance, 59(3), 1301-1328. https: / / doi.org/10.1111/1540-6261.00567

Anderson, R. C. \& Reeb, D. (2004). Board composition: balancing family influence in S\&P 500 firms. Administrative Science Quarterly, 49(2), 209-237. https: / /doi.org/10.2307/4131472

Baltagi, B. H. (1995). Econometric analysis of panel data, Chichester: John Wiley \& Sons,

Bartholomeusz, S. \& Tanewski, G.A. (2006). The relationship between family firms and corporate governance. Journal of Small Business Management, 42(2), 245-67.

Ben-Amar, W. \& André, P. (2006). Separation of ownership from control and acquiring firm performance: The case of family ownership in Canada. Journal of Business Finance \& Accounting, 33(3\&4), 517-543. https://doi.org/10.1111/j.1468-5957.2006.00613.x

Boyd, B. K. (1995). CEO duality and firm performance: A contingency model. Strategic Management Journal, 16(4), 301-312. https://doi.org/10.1002/ smj.4250160404

Bozec, R. \& Dia, M. (2007). Board structure and firm technical efficiency: Evidence from Canadian state-owned enterprises. European Journal of Operational Research, 177, 1734-1750. https://doi. org/10.1016/j.ejor.2005.10.001

Bozec, Y. \& Laurin, C. (2008). Large shareholder performance and entrenchment: Empirical evidence from Canada. Journal of Business Finance \& Accounting, 35(1\&2), 25-49. doi: 10.1111/j.14685957.2007.02066.x

Brickley, J. A., Coles, J. L., \& Jarrell, G. (1997). Leadership structure: Separating the CEO and chairman of the board. Journal of Corporate Finance, 3, 189-220. https://doi.org/10.1016/S09291199(96)00013-2

Cambieri, G. (2012). Infographic: Brazilian family businesses. Campden FB, available at: http://www. campdenfb.com/article/infographic-brazilian-family-businesses (accesed 15 november 2018).

Carney, M. (2005). Corporate goverance and competitive advantage in family conrolled firms. Enterpreneurship Theory and Practice, 29, 249-265. https://doi.org/10.1111/j.1540-6520.2005.00081.x

Carter, D. A., D’Souza, F., Simkins, B. J., \& Simpson, G. W. (2010). The gender and ethnic diversity of US boards and board committees and firm financial performance. Corporate Governance: An International Review, 18(5), 396-414. https://doi. org $/ 10.1111 /$ j.1467-8683.2010.00809.x

Chen, Z., Cheung, Y., Stouraitis, A., \& Wong, A. (2005). Ownership concentration, firm performance, and dividend policy in Hong Kong. PacificBasin Finance Journal, 13, 431-449. https://doi. org/10.1016/j.jcorpfin.2017.01.001
Chen, J., Leung, W. S., \& Goergen, M. (2017). The impact of board gender composition on dividend payouts. Journal of Corporate Finance, 43, 86-105. https: //doi.org/10.1016/j.jcorpfin.2017.01.001

Claessens, S., Djankov, S., \& Lang, L. (2000). The separation of ownership and control in East Asian Corporations. Journal of Financial Economics, 58(1-2), 81-112. https://doi.org/10.1016/S0304405X(00)00067-2

Chong, A. \& López de Silanes, F. (2007). Corporate governance in Latin America, Washington, D.C.: Inter-American Development Bank.

Crisóstomo, V. L., Iturriaga, F. J., \& González, E. V. (2013). Financial constraints for investment in Brazil. International Journal of Managerial Finance, 10, 73-92. https://doi.org/10.1108/IJMF-11-20120121

Cueto, D. C. \& Switzer, L. N. (2015). Intraday market liquidity, corporate governance, and ownership structure in markets with weak shareholder protection: Evidence from Brazil and Chile. Journal of Management \& Governance, 19(2), 395-419. https://doi.org/10.1007/s10997-013-9263-8

Dalton, D. R., Daily, C. M., Ellstrand A. E., \& Johnson, J. L. (1998). Meta-analytic reviews of board composition, leadership structure, and financial performance. Strategic Management Journal, 19(3), 269-290. https://doi.org/10.1002/(SICI)10970266(199803)19:3<269::AID-SMJ950>3.0.CO;2-K

Easterbrook, F. (1984). Two agency cost explanations of dividends. American Economic Review, 74, 650-659.

EY (2014). Family business yearbook 2014. Available at: http://portal.firmyrodzinne.eu/system/files/ attachments/family_business_yearbook_2014.pdf (Accessed 15 October 2018).

Faccio, M., Lang, L. H. P., \& Young, L. (2001). Dividends and expropriation. American Economic Review, 91(1), 54-78.

Fama, E. \& Jensen, M. (1983). Separation of ownership and control. Journal of Law and Economics, 26(2), 301-325. https://doi.org/10.1086/467037

Farinha, J. (2003). Dividend policy, corporate governance and the managerial entrenchment hypothesis: An empirical analysis. Journal of Business Finance and Accounting, 30(9-10), 1173-1209. https://doi. org/10.1111/j.0306-686X.2003.05624.x

Family Firm Institute (2016). Global data points. FFI Global Education Network.

Fatemi, A. \& Bildik, R. (2012). Yes, dividends are disappearing: Worldwide evidence, Journal of Banking \& Finance, 36, 662-677. https://doi.org/10.1016/j. jbankfin.2011.10.008

Francoeur, C., Labelle, R., \& Sinclair-Desgnane, B. (2008). Gender diversity in corporate governance and top management. Journal of Business Ethics, 81(1), 83-95. https://doi.org/10.1007/s10551-0079482-5

Gersick, K. E., Davis, J. H., Hampton, M. M., \& Lansberg, I. (1997). Generation to generation: Life cycles of the family business. Boston: Harvard Business School Press.

Gómez-Mejía, L. R., Makri, M., \& Larraza-Kintana, M. (2010). Diversification decisions in familycontrolled firms. Journal of Management Studies, 47, 223-252. https://doi.org/10.1111/j.14676486.2009.00889.x 
González, M., Guzmán, A., Pombo, C., \& Trujillo, M. A. (2014). Family involvement and dividend policy in closely held firms. Family Business Review, 27(4), 365-385. https://doi. org/10.1177/0894486514538448

González, M., Molina, C., Pablo, E., \& Rosso, J. (2017). The effect of ownership concentration and composition on dividends: Evidence from Latin America. Emerging Markets Review, 30, 1-18. https://doi.org/10.1016/j.ememar.2016.08.018

Gul, F., Srinidhi, B., \& Ng, A. C. (2011). Does board gender diversity improve the informativeness of stock prices? Journal of Accounting and Economics, 51(3), 314-338. https://doi.org/10.1016/j.jacceco.2011.01.005

Gunasekarage, A. \& Reed, D. K. (2008). The market reaction to the appointment of outside directors: An analysis of the interaction between the agency problem and the affiliation of directors. International Journal of Managerial Finance, 4(4), 248258. https: / /doi.org/10.1108/17439130810902787

Gutiérrez, M., Yañez, M., \& Umaña, B. (2012). Análisis de la política de pago de dividendos en empresas chilenas. Estudios Gerenciales, 28(123), 27-42. https://doi.org/10.1016/S0123-5923(12)70203-6

Harjoto, M., Laksmana, I., \& Lee, R. (2015). Board diversity and corporate social responsibility. Journal of Business Ethics, 132(4), 641-660. https:// doi.org/10.1007/s10551-014-2343-0

Hossain, M., Prevost, A. K., \& Rao, R. P. (2001). Corporate governance in New Zealand: The effect of the 1993 companies Act on the relation between board composition and firm performance. Pacific Basin Finance Journal, 9(2), 119-145. https://doi. org/10.1016/S0927-538X(01)00003-8

Huse, M. \& Solberg, A. G. (2006). Gender-related boardroom dynamics: How Scandinavian women make and can make contributions on corporate boards. Women in Management Review, 21(2), 113130. https: //doi.org/10.1108/09649420610650693

IBFD (2017). Doing business in Chile. International Bureau of Fiscal Documentation (IBDF).

Jensen, M. (1986). Agency cost of free cash flow, corporate finance, and takeovers. American Economic Review Papers and Proceedings, 76, 323-329.

Jensen, M. \& Meckling, W. (1976). Theory of the firm: Managerial behavior, agency costs and ownership structure. Journal of Financial Economics, 3, 305360. https://doi.org/10.1016/0304-405X(76)90026-X

Jensen, M. C. (1993). The modern industrial revolution, exit and the failure of internal control systems. Journal of Finance, 48(3), 831-880. https:// doi.org/10.1111/j.1540-6261.1993.tb04022.x

Jurkus, A. F., Park, J. C., \& Woodard, L. S. (2011). Women in top management and agency costs. Journal of Business Research, 64(2), 180-186. https:// doi.org/10.1016/j.jbusres.2009.12.010

Kang, H. \& Kim, J. (2016). Why do family firms switch between family CEOs and nonfamily professional CEO? Evidence from Korean Chaebols. Review of Accounting and Finance, 15(1), 45-64. https://doi. org/10.1108/RAF-03-2015-0032f

Khan, T. (2006). Company dividends and ownership structure: Evidence from UK panel data. Economic Journal, 116(510), 172-189. https://doi. org/10.1111/j.1468-0297.2006.01082.x
Klein, A. (2002). Audit committee, board of director characteristics, and earnings management. Journal of Accounting and Economics, 33(3), 375-400. https://doi.org/10.1016/S0165-4101(02)00059-9

La Porta, R., Lopez-de-Silanes, F., \& Vishny, R. W. (1998). Law and finance. Journal of Political Economy, 106(6), 1113-1155. https://doi. org $/ 10.1086 / 250042$

La Porta, R., Lopez-de-Silanes, F., \& Shleifer, A. (1999). Corporate ownership around the world. Journal of Finance, 54, 471-517. https://doi. org/10.1111/0022-1082.00115

La Porta, R., Lopez-de-Silanes, F., Shleifer, A., \& Vishny, R. (2000). Agency problems and dividend policies around the world. Journal of Finance, 55(1), 1-33. https://doi.org/10.1111/00221082.00199

Laux, G. (2006). Mercado de crédito no Brasil: Características e respostas a choques, Master dissertation, Fundação Getulio Vargas - Escola de Economia de São Paulo.

Leal, R. P. C. \& Carvalhal-da-Silva, A. L. (2007). Corporate governance and value in Brazil (and in Chile). In A. Chong \& F. Lopez-de-Silanes (Eds.), Investor protection and corporate governance: Firmlevel evidence across Latin America. World Bank Publication. Stanford University Press.

Lefort, F. \& Walker, E. (2000). Ownership and capital structure of Chilean conglomerates: Facts and hypothesis for governance. Revista Abante, 3(1), 3-27.

Lefort, F. \& Walker, E. (2007). Corporate governance, market valuation, and payout policy in Chile. In: Chong, A. \& F. López-de-Silanes (Eds.), Investor protection and corporate governance: Firm level evidence across Latin America (pp. 289-352). New York: Stanford University Press.

Lozano, M. B. \& Caltabiano, S. (2015). Cross-institutional cash and dividend policies: focusing on Brazilian firms, Applied Economics, 47(3), 239-254. https: / /doi.org/10.1080/00036846.2014.967516

Martins, T. C. \& Novaes, W. (2012). Mandatory dividend rules: Do they make it harder for firms to invest? Journal of Corporate Finance, 18, 953-967. https://doi.org/10.1016/j.jcorpfin.2012.05.002

Maug, E. (2002). Insider trading legislation and corporate governance. European Economic Review, 46(9), 1569-1597. https://doi.org/10.1016/S00142921(02)00243-X

McKinsey \& Company (2014). Perspectives on founder- and family-owned businesses. McKinsey \& Company.

Michaely, R. \& Roberts, M. R. (2012). Corporate dividend policies: Lessons from private firms. Review of Financial Studies, 25(3), 711-746. https://doi. org/10.1093/rfs/hhr108

Michiels, A., Voordeckers, W., Lybaert, N., \& Steijvers, T. (2015). Dividends and family governance practices in private family firms. Small Business Economics, 44, 299-314. https://doi. org/10.1007/s11187-014-9594-0

Miguel, A., Pindado, J., \& de la Torre, C. (2005). How do entrenchment and expropriation phenomena affect control mechanisms? Corporate Governance: An International Review, 13, 505-516. https://doi. org/10.1111/j.1467-8683.2005.00445.x 
Miller, M. H. \& Modigliani, F. (1961). Dividend policy, growth, and the valuation of shares. Journal of Business, 34(4), 411-433.

Miller, D., Le Breton-Miller, I., \& Lester, R. H. (2010). Family ownership and acquisition behavior in publicly-traded companies. Strategic Management Journal, 31, 201-223. https://doi.org/10.1002/ smj.802

Parada, M. J., Müller, C., \& Gimeno, A. (2016). Family firms in Ibero-America: An introduction. Academia Revista Latinoamericana de Administración, 29(3), 219-230. https://doi.org/10.1108/ARLA-052016-0128

Pindado, J., Requejo, I., \& de la Torre, C. (2012). Do family firms use dividend policy as a governance mechanism? Evidence from the Euro zone. Corporate Governance: An International Review, 20(5), 413-431. https://doi.org/10.1111/j.14678683.2012.00921.x

Pucheta-Martínez, M. C., Bel-Oms, I., \& Olcina-Sempere, G. (2016). Corporate governance, female directors and quality of financial information. Business Ethics: A European Review, 25(4), 363-385. https://doi.org/10.1111/beer.12123

Roy, A. (2015). Dividend policy, ownership structure and corporate governance: An empirical analysis of Indian firm. Indian Journal of Corporate Governance, 8(1), 1-33. https://doi. org/10.1177/0974686215574422

Schio, L. (2017). Understanding the family businesses: A case study from Brazil, Thesis dissertation, Massachusetts Institute of Technology, MIT Sloan School of Management. USA.

Setia-Atmaja, L. (2010). Dividend and debt policies of family controlled firms. The impact of board independence. International Journal of Managerial Finance, 6(2), 128-142. https://doi.org/10.1111/ j.1468-5957.2009.02151.x

Setia-Atmaja, L., Tanewski, G., \& Skully, M. (2009). The role of dividends, debt and board structure in the governance of family controlled firms. Journal of Business Finance and Accounting, 36(78), 863-898. https://doi.org/10.1111/j.14685957.2009.02151.x

Shleifer, A. \& Vishny, R. (1997). A survey of corporate governance. Journal of Finance, 52, 737-783. https://doi.org/10.1111/j.1540-6261.1997.tb04820.x

Villalonga, B. \& Amit, R. (2006). How do family ownership, control and management affect firm value? Journal of Financial Economics, 80, 385-417. https://doi.org/10.1016/j.jfineco.2004.12.005

Watkins-Fassler, K., Fernández-Pérez, V., \& Rodríguez-Ariza, L. (2016). President interlocking, family firms and performance during turbulent times: Evidence from Latin America. European Journal of Family Business, 6, 63-74. http:// dx.doi.org/10.1016/j.ejfb.2016.12.001

Yang, M. L. (2010). The impact of controlling families and family CEOs on earning management. Family Business Review, 23(3), 266-279. https://doi. org/10.1177/0894486510374231

Yoshikawa, T. \& Rasheed, A. (2010). Family control and ownership monitoring in family-controlled firms in Japan. Journal of Management Studies, 47, 274-295. https://doi.org/10.1111/j.14676486.2009.00891.x
Zagonel, T., Soares, P., \& Favero, D. (2018). Taxation, corporate governance and dividend policy in Brazil. RAUSP Management 